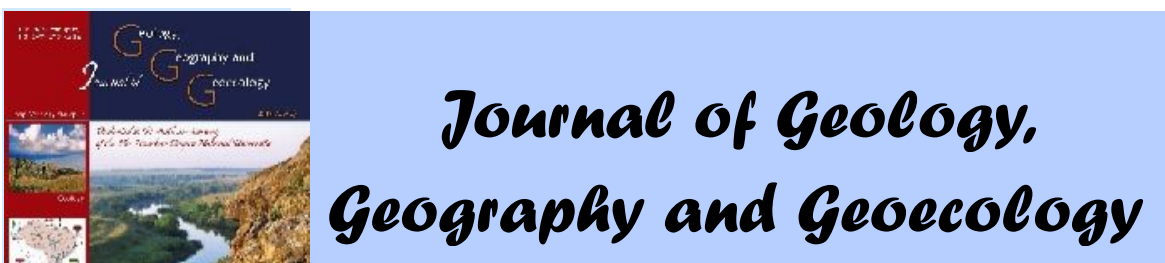

Journal home page: geology-dnu-dp.ua

Journ.Geol.Geograph. Geoecology, 27(2), 294-304 doi: $10.15421 / 111853$ E.O. Maksymova, S.I. Kostrytska.

Journ.Geol.Geograph.Geoecology, 27(2), 294-304

\title{
Geological and structural prerequisites of gas-bearing capacity and gas hydrate formation in the World Ocean (in terms of the Black Sea)
}

\author{
Ella Maksymova, Svitlana Kostrytska
}

National Mining University, Dnipro,Ukraine, email: elmaks28@gmail.com; inmovnmu@gmail.com

Received 09.05.2018;

Received in revised form 16.052018; Accepted 20.06.2018
Abstract.Gas hydrates occurring in the World Ocean are considered as the additional and perspective non-traditional resource of hydrocarbon materials. The proposed classification of deposits as for mining and geological conditions of their occurrence as well as methodological approach to their development and calculation of technological parameters of methane extraction from the World Ocean floor with minimum impact upon the Earth's hydrosphere is of considerable importance in the context of current studies of new and most prospective source of energy in terms of the available experience gap as for the development of gas hydrate deposits. The approach to search for and explore gas hydrate deposits occurring on and under the World Ocean floor has been suggested; the approach is based upon the regularities of gas hydrate distribution in lithological varieties and geological structures. The necessity to take into consideration the pore space enclosing gas hydrate thicknesses to calculate their reserves has been substantiated. The overview of scientific literature sources summarizing the results of marine expeditions as well as the analysis of publications of world scientific community dealing with the studies of gas hydrates has made it possible to determine that gas hydrate deposits are associated to the zones of jointing of continental plates and oceanic troughs. In their turn, those zones, due to different genesis, are made up of the corresponding various products of sedimentary rock accumulations. Detailed analysis of the Black Sea floor structure has been performed. Three geomorphological zones have been singled out; basic types of gas-bearing capacity manifestation and methane liberation from the interior have been represented. Quantitative evaluation of methane content in gas hydrate deposits has been given taking into account the detected ones. Data concerning gas-bearing capacity of the Black Sea floor proved by the map of mud volcanoes location within the areas of gas hydrate sampling have been considered. That was the basis to analyze peculiarities of the formation of bottom-sediment gas hydrates basing upon genetic origin of lithological composition of their enclosing rocks and their structures in terms of the Black Sea floor. Relation between the features of the World Ocean floor structure and the distribution of gas hydrate deposits has been determined. Theoretical approach to search for and explore gas hydrate deposits both in the Black Sea and in the World Ocean has been developed and proposed. Interaction between different zones of the World Ocean floor and types of gas hydrate deposits based upon the compositions of their enclosing rock has been shown. Lithological composition of the rocks enclosing gas hydrates has been analyzed in detail. That will make it possible to determine the type of any specific deposit and elaborate technological scheme to open and develop methane-containing gas hydrate deposits.

Key words: the Black Sea, the World Ocean, gas hydrate, methane, bottom sediments.

\section{еолого - структурні передумови г зоносності т гідр тоутворення в вітовому оке ні (н прикл ді орного моря)}

\author{
. . ксимов , . . острицьк
}

ержк вний вищий н вч льний $з$ кл д « ціон льний гірничий університет», ніпро, кр їн , email:elmaks28@gmail.com; inmovnmu@gmail.com

нот ція. одовищ г зових гідр тів є перспективним дод тковим джерелом вуглеводневої сировини. суч сному ет пі досліджень цього нового і н йбільш перспективного джерел енергетичних ресурсів, м є велике зн чення розробк технологічних п р метрів процесу вилучення мет ну з дн вітового оке ну з мінім льним впливом н гідросферу емлі. ля досягнення цієї мети, є вельми кту льним вст новлення геолого-структурних особливостей з ляг ння цього ресурсу, виявлення з кономірностей його поширення в донних відкл деннях т оцінк впливу літологічного скл ду порід, що вміщують г зогідр т н формув ння його структур. пропонов н кл сифік ція родовищ г зових гідр тів, що 3 ляг ють н дні і під дном вітового оке ну, з снов н н 3 кономірностях їх поширення в різних літологічних різновид $\mathrm{x}$ і геологічних структур х, н д є можливості для їх пошуку і розвідки. бгрунтов но необхідність вр хув ння оцінки порового простору, що 
вміщ є г зогідр тні товщі для підр хунку їх з п сів. икон но дет льний н ліз будови дн орного моря, виділені три геоморфологічних зони і н ведені основні види прояви г зоносності і виділення мет ну з н др. цій основі викон но н ліз особливостей формув ння г зогідр тів донних відкл день, н основі генетичного походження літологічного скл ду порід, що вміщують і їх структур, н прикл ді дн орного моря. ур хув нням виявлених родовищ г зових гідр тів, н веден кількісн оцінк вмісту мет ну в г зогідр тних відкл деннях.

лючові слов : орне море, вітовий оке н, г зовий гідр m, мет н, донні відкл дення.

Introduction. International scientific community considers huge deposits of gas hydrates in the World Ocean as the extra nontraditional source of carbohydrates. Studies of gas hydrates have become more active in recent 50 years. Many of scientists from different countries discuss the issues concerning the availability of gas hydrates and conditions of gas hydrate formations. Over that period, various scientists (Okuda, 1988; Kvenvolden, Robertson, Simons, 1988;Shnyukov, Gozhik, Krayushkin, Klochko, 2007; Makogon, 2010; Chen, Zhou, Su, Liu, Lu, Wang, 2011; Kobolev, 2017 and others) have determined the availability of gas hydrates within the mainland and considerable occurrences of gas hydrate deposits within the shelf and floor of the World Ocean. Such authors as Sloan, 1990; Yamamoto, Terao, Fujii, Ikawa, Seki, Matsuzawa, Kanno, 2014; Zhao, Song, Lim, Lam, 2017) state that gas hydrate reserves $\left(21016 \mathrm{~m}^{3}\right)$ are comparable to the amount of oxygen in the Earth's atmosphere (8 $\left.1017 \mathrm{~m}^{3}\right)$. Taking into consideration high specific gas concentration in natural hydrates (up to $160 \mathrm{~m} / \mathrm{m}^{3}$ ), their relatively shallow occurrence (under seafloor starting from the water depth of 300-500 m) (Byakov, Krugliakova2001), deep-sea hydrates are considered as a real alternative to the traditionally extracted gas. Nowadays, Great Britain, Germany, Canada, China, the USA, Norway, and Japan are involved in the development of gas hydrate extraction technologies.

Japanese and Canadian researchers have made successful attempts of gas hydrate deposit development. In 2012, Japan initiated one of the top-priority national budget-financing programmers in the world aimed at the development of marine gas hydrate deposits of Nankai Trough at the depth of $950 \mathrm{~m}$ (Yamamoto, Terao, Fujii, Ikawa, Seki, Matsuzawa, Kanno, 2014). For the first time in the world practice, Japanese gas enterprise has managed to extract gas from the seafloor gas hydrates. The extraction may be called as a well production testing. For instance, Canadian experts have extracted gas from the gas hydrates deposits located within the permafrost zone. Irrespective the facts that gas emission was stable only during six days and the experiments cost CDN $48 \mathrm{mln}$, scientific community took the news as a real breakthrough in the sphere of "blue fuel" extraction as Arctic area of Canada is characterized by gas hydrate deposits being sufficient to satisfy the needs of Canadian domestic market for some hundred years to come.
Topicality of the research is proved by the no availability of both direct and indirect methods to search and explore gas hydrate deposits within the World Ocean floor apart from geophysical one. Geophysical methods are widely applied by modern science to detect such deposits, taking into consideration specific features of their occurrence and expansion. However, to plan any geophysical expeditions, it is important to have previous outline of the zone for searching and exploring; further evaluation of the deposits requires innovative approach considering pore space, facility, and enclosing rock structure. The paper proposes to predict these parameters according to the bottom structure before the beginning of deep drilling operations.

The author deals with the problem not only in terms of the obtaining additional power resource, but also because of the concerns that there may be serious environmental and climatic problems as a result of possible accidental methane release into the atmosphere not only during incorrect development of gas hydrate deposits but also in the context of relatively minor changes in thermodynamic (climatic) conditions being close to the limit of gas hydrate phase stability (Bondarenko, Maksymova, Koval 2013; Maksymova, 2015, 2016, 2018). In other words, as a result of global warming and increase in the World Ocean temperature, deep-sea gas hydrates may begin their uncontrollable decomposition even without human involvement as the shift in phase balance in terms of environmental temperature rise will result in chain reaction of gas liberation. That is true about the Black Sea as well. Currently, there is no scientifically substantiated technology to develop gas hydrate deposits. Rational development of that additional natural energy resource requires the elaboration of a technological scheme taking into consideration the specific geological and morphological structure of each deposit as well as the utmost environmentally friendly technology of gas extraction from gas hydrate deposits. Thus, the main task for today is to formulate a complex approach for that natural resource development. With respect to the available wide-scale worldwide studies in the area, it is obvious that we need detailed analysis of the relations of all the processes within the considered systems from the viewpoint of geological conditions and regularities.

Thus, the objective of the paper is to demonstrate the relations between the World Ocean floor 
peculiarities and the occurrence of gas hydrate deposits, depending upon the enclosing rock composition, for their further possible development.

Analysis of publications. According to the results of scientific papers by E.F. Shnyukov, V.P. Kobolev, A.A. Pasinkov and others (Shnyukov, Kobolev, Pasyinkov 2013; ShnyukovE, Ziborov 2004;Lee, Ryu, Yun, Cho, 2011), generalized complex stateof-the-art study has been carried out to identify and explore gas hydrate deposits by the expeditions from different countries.

Analysis and comparison of numerous maps and aerial survey data of the identified deposits of gas hydrates and zones of global tectonic faults prove the association of the majority of the deposits to the zones of joints of continental plates and abyssal depths [Maksymova, 2013, 2015]. In their turn, due to different genesis, those zones are made up from the corresponding products of sediment accumulation.

The Black Sea floor has been the subject of study since antiquity. According to the conclusions of the international oceanographic expedition by "Aquanaut" research vessel in 1993, one of the hypotheses of the Black Sea origin tells that 7500 years ago there was the planet deepest aquatic lake which level was lower than the modern one by more than $100 \mathrm{~m}$. When the Glacial Era was over, the World Ocean level rose and the Bosporus strait was breached. 100 thousand $\mathrm{m}^{2}$ of fertile lands being already cultivated were flooded. According to the hypothesis, the Black Sea origin was possibly accompanied by mass mortality of all the lake fresh-water life which decomposition products were represented by methane and hydrogen sulphide. In 1996 , theory of the Black Sea flood was also proposed by the geologists William Rayan and Walter Pitman (University of Columbia, the USA); according to their theory there was a massive and catastrophic rise of the Black Sea level (about 5600 B.C.).

Insummer 1890, an expedition headed by I.B. Shpindler equipped 37 deep-water stations; 889 different-depth temperature measurements, 446 specific gravity tests, and 12 draggings were performed. Thus, following facts were proved:

floorofthecentralBlackSeapartis abasinbeingexclusivelyflat, stretchedapproximatelyfromwesttoeast, withthedepthdownto $2244 \mathrm{~m}$;

- watertemperaturebeginningfromthedepthof $200 \mathrm{~m}$ and down to the floor is uniform being about $9^{\circ}$;

salinityatthosedepthsincreasesdowntothefloorveryslowly (upto $22 \mathrm{~g} / \mathrm{l}$ ), atthesametimeitdifferssharplyfromthesalinityofthelayerslocatedhigher (about $17 \mathrm{~g} / \mathrm{l}$ );

- in the summer time, in some places, water temperature down to $50 \mathrm{~m}$ is heated up to $25 \mathrm{de}$ grees, then, down to the depth of $100 \mathrm{~m}$, one can observe water layers with the temperature of about 7 degrees;

- at the depth lower than $200 \mathrm{~m}$ the water is saturated with hydrogen sulphide, there are no living organisms, and scallops occur in deep deposits that is characteristic only for fresh-water limans.

The deepest water is $2250 \mathrm{~m}$ along the axis opposite the Crimean Peninsula. The fact of coincidence in the directions of main axes of basins and axes of mountain folds in the Crimea is of special interest. Orientation of folds in the Crimean Mountains has two systems: the first one is from the north-east to the south-west; the second one is from the south-east to the north-west. The first system being also characteristic for the Balkan folds, is the basic one, it coincides with the direction of the axis of the deepest trough in the Black Sea. The second fold system, corresponding to the folds of the Caucasus Mountains, coincides with the greatest axis of the eastern sea basin.

Thus, the first Black Sea oceanographic survey was crowned with the greatest oceanographic discoveries. Later, there were organized numerous expeditions which confirmed those five key findings.

Retrospectively, gas ingresses were widely highlighted in scientific papers by such geologists as Byakov, R.P. Krugliakova and many other researchers (Byakov, Krugliakova2001; Shnyukov, Ziborov 2004). Great contribution into the study and systematization of the data concerning structure, gasbearing capacity, and gas hydrates of the Black Sea was made by P.F. Gozhik, V.I. Starostenko, E.F. Shnyukov, V.P. Kobelev, A.E. Lukin (Shnyukov, Gozhik, Krayushkin, Klochko , 2007; Shnyukov, Kobolev, Pasyinkov 2013; Lukin. 2014).

Material and research methods. The paper uses methodically a system analysis of the available gas hydrate deposits, proves the possibility of their extraction, and, considering certain difficulties in carrying out the detailed exploration, develops theoretical approach based upon previous evaluation and mining and geological conditions of the distribution of such deposits. The proposed classification approach to search and explore economically expedient, in terms of methane extraction, zones of the World Ocean floor is of high value at the present stage of studying new additional and the most prospective source of energy resources. For the first time, the interrelation of different zones of the World Ocean floor and the types of gas hydrate deposits has been demonstrated on the basis of their genetic origin and enclosing rock structure.

The basis of theoretical considerations as for 
the regularities of the formation of gas hydrate deposits is represented by the key concept: relying upon a genetic origin and mining and geological belonging to one or another ocean floor structure, there will be different thermobaric conditions for the be-ginning of gas hydrate formation and deposits accumulation taking into consideration corresponding composition of lithological variations of the enclosing rocks. Floor thickness is represented by the substances ranging from finely dispersed aluminum silicate deposits to quartz fine-grained sands and coarse size breccia of various mineralogical composition of rock-forming thicknesses; it also has indices of heat conductivity, specific heat capacity, porosity, and permeability, being unique for each deposit, that should be also taken into account while selecting the technique for a specific deposit development.

Results and their analysis. There are three basic geomorphological elements within the Black Sea water area: shelf, continental slope, and deep-sea trough. The Black Sea shelf is a flat underwater slope spreading down to $90-150 \mathrm{~m} .10-12$ thousand years ago it was a plain where rivers flew. When last glaciers melt and retreated to the north, those plains turned to be flooded. Now the shelf covers $24 \%$ of the Black Sea floor area. Its width varies. In the north-west, shallow marine shelf stands out to the sea by $200-250 \mathrm{~km}$; at Caucasian and Asia Minor coasts is stands out to the sea only by $6-10 \mathrm{~km}$; somewhere it even ends abruptly at $500 \mathrm{~m}$ from the coast. Continental slope is represented by a narrow zone of a steep turn of a seafloor from the outer shelf down to the depth of $1830 \mathrm{~m}$ with the steepness of 20-30 degrees. Deep-sea trough of the Black Sea (36\% of its water area) is elongated from the west to the east in the form of oval; it bends slightly to the north, its floor is relatively flat, and depths are deeper than $2000 \mathrm{~m}$ (Fig.1).

According to the results of the expeditions of the Ministry of Geology of AS of the USSR and the Ministry of Higher Education Institutions of the USSR (1988-1989), deposits of gas hydrate methane and natural gas were found in the Black Sea at the depths of 200-800 m with the thickness of 250-1200 m located lower than the seafloor level with layer thicknesses accounting for dozens of meters.

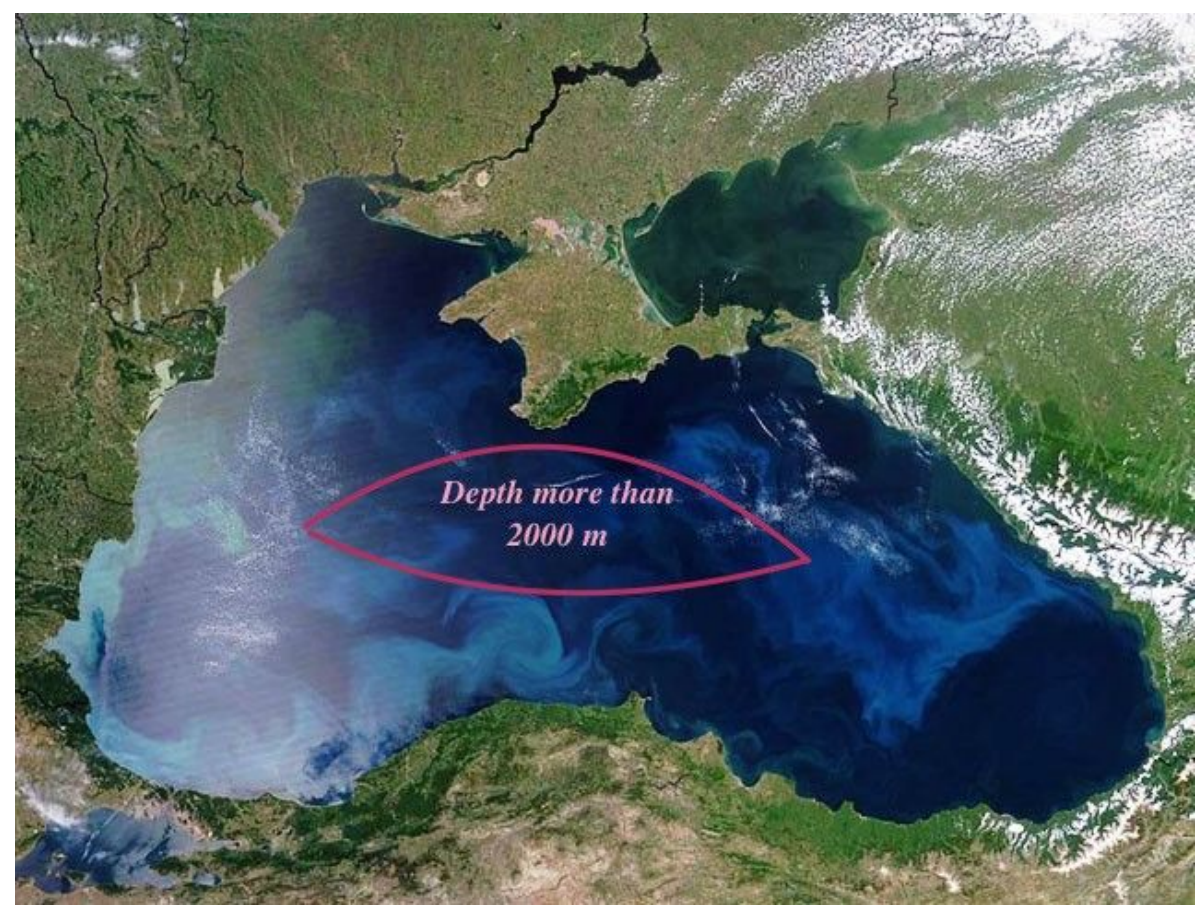

Fig.1.The Black Seabasin. A lens demonstrates the depths being more than 2000 m. Photo NASA.

Methane resources in gas hydrate deposits opposite the Crimea are estimated to be 20-25 trn $\mathrm{m}^{3}$; the research carried out by the expeditions of the Ministry of Geology of AS of the USSR and the Ministry of Higher Education Institutions of the USSR (1988-1989) shows that according to the seabed drilling and gas hydrate sampling in terms of more than 400 test cores, the amount of methane within the whole Black Sea shelf is not less than 100 trn $\mathrm{m}^{3}$.
First methane bursts took place as a result of the Crimean earthquake, 11 September 1927. A burst of flame being about $500 \mathrm{~m}$ high and 1.5mile-wide was recorded to the east from Sevastopol. Similar bursts were observed from the lighthouse in Yevpatoria; at that, bursts in the form of hot clouds were moving from the north to the south. According to the earthquake description by A.L. Nikonov, within the period from 14 September 1927 to 5 October 1927, columns of white vapor 
over the sea surface as well as burning clouds, flames, and even fire columns immersing into the sea with hissing and bursting into flame again were observed near Alushta, Alupka, and Sudak as well as towards Pryvitne settlement and Feodosia.

From the geographical viewpoint, it is obvious that such gas-bearing capacity is characteristic for different geological structures of the Black Sea floor. If near Yevpatoria it is associated to the continental shelf, then opposite Alushta, Alupka, Sudak it is associated to a much deeper continental slope or even to Sorokin Trough. The latter conclusion is proved by the results of the expedition by the Academic Research Fleet of Ukraine (Shnyukov, Kobolev, Pasyinkov 2013). Abundant gas occurrences are recorded near the coastline of Bulgaria.

Numerous researchers consider the Black Sea as a unique basin in terms of its gas-bearing capacity as it is characterized by rather high seabed gas recovery comparing to other basins of the World Ocean with the discovered hydrocarbon reserves. According to the results of American re- search expedition by "Knorr" vessel, methane reserves in the Black Sea are 88 bln $\mathrm{m}^{3}$.

According to the results of expedition by "Professor Vodianytsky" research vessel (20022006), it is determined that if methane seeps from the Earth's interior very deep underwater, then gas is formed into a gas hydrate deposit. However, sometimes-unconfined major gas releases break gas hydrate formations. The expedition proved the fact that all the large flames preserved their location and intensity that increased the chances for perspective oil and gas extraction. About 50 mud volcanoes were discovered; however, scientists state that their number is much greater. According to Yevhen Shnyukov, marine geologist, academician of the Academy of Sciences of Ukraine, discharges of some mud volcanoes are similar to some famous Caspian ones where eventually extensive oil fields were established. One more peculiarity of the Black Sea floor is the availability of methane gas hydrate caps; about 20 of them are already found (Fig. 2). Sorokin Trough located $40 \mathrm{~km}$ to the south-east from Yalta is one of the most prospective areas of the seabed; the through depth is $2 \mathrm{~km}$.

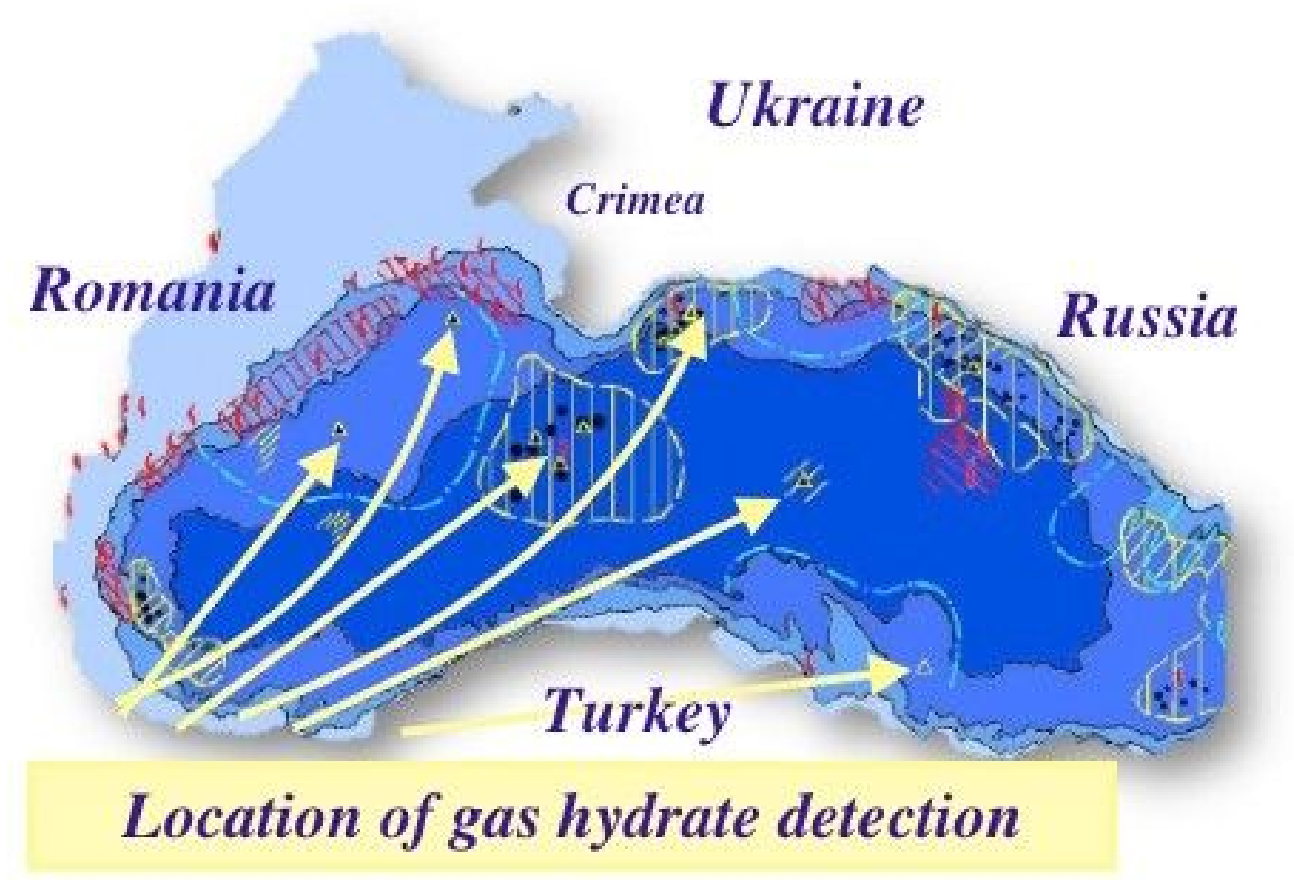

Fig. 2.AreasofgashydratesintheBlackSeadetected during the expedition by "Professor Vodianytsky" research vessel [Shnyukov, Kobolev, Pasyinkov 2013]

Gas hydrate discoveries are located within the large geological structures both in Eastern Black Sea and Western Black Sea troughs. Some scientists (Lozynskyi, Saik, Petlovanyi, Sai, Malanchyk, 2018) consider that only from 1 to 10 $\%$ of gases entering the hydrate formation zone are stabilized in gas hydrates.
Perspective areas to search for gas hydrates also include: continental slope (from the depths of $700-800 \mathrm{~m}$ to its foot), paleodel deposits of the river fans (Kobolev, Verpakhovskaya, 2014), zones of mud streams and zones of displacements, and zones with the developing diaper structure, first of all, the ones formed by mud volcanoes. Gas-bearing 
area is also the one represented by the whole territory of central Black Sea fault being the basis for the development of the continental slope as well as the areas of deep and regional faults located deep in the sea, zones of diaper development complicated by mud volcanism, and, possibly, zones of deep-sea subma-rine discharge. Sorokin Trough is also considered to be a perspective area.

Special attention should be paid to paleodel deposits. Considerable occurrences of gas-saturated sludge and gas hydrates can be observed here. Bed deposits contain methane which concentration is by 3-4 times more than the background values. The sampled gases include hydrogen sulphide, methane, and heavy hydrocarbons.

According to the results of the Black Seas seismic and geoacoustic surveying, numerous anomalies demonstrating the availability of gas hydrates were singled out. Such areas are known within the western part of the trough, barrier anticlinal zone, Palas Rise, Sorokin Trough, Anapa Rise, and at the foot of the Caucasian continental slope. More than a dozen of gas hydrate discoveries in the surface layer of bed deposits were recorded in the Black Sea; bed deposit interval was 0.6-2.85 m (within the Crimean continental slope, Palas Rise etc.). Gas hydrate methane deposits with the thickness of 400-800 $\mathrm{m}$ under the seabed were found within some areas of the Black Sea at the depth of 300-1000 m.

Geological and geophysical data and literature sources by the scientists of the NAS IGS of Ukraine who studied north-west and KerchFeodosia areas of the Black Sea basin shelves were used to develop a map of the perspective structures of gas hydrates and hydrocarbon deposits.

Thestartofhydrocarbonexplorationinthatregiondatesbacktothe 1950s. In 1976, the research carried out by seismic survey robots of the Black Sea geophysical expedition by "Krymmorheologiia" association (Gruzer, F.L. and others) proved the availability of Kerch-Taman periclinal transverse trough; in addition, Southern-Kerch and Subotin structures were determined in association with "Yuzhmorheo" CGE RMA. In 1978-1982, comprehensive maps of different levels of Meso-Cenozoic Subotin, Sokolov, Hlyboka etc. structures were developed basing upon the detailed seismic surveying carried out by "Soiuzmorheo".

According to the detailed seismic surveying with the application of modern techniques, Subotin structure is among the largest ones in terms of local structures determined within Kerch shelf. In 2005, a parametric well No. 403-Subotin was drilled within the vault part of Subotin structure; the purpose was to specify lithological and stratigraphic differentiation of the opened section as well as its facies and formation characteristics, to study conditions of the occurrence of perspective Cretaceous-Neogene complexes, to obtain geological and geophysical parameters for lithological and stratigraphic association, to understand the levels, data on physical properties of rocks as well as physical and chemical characteristics of the formation fluids required to inter-pret seismic exploration commercial and geophysical studies, to define perspectives of oil-andgas bearing capacity of the opened section, and to refine the evaluation of the unexplored hydrocarbon resources. Target well depth is $4300 \mathrm{~m}$; true well depth is 4300; target level is Paleocene-Upper Cretaceous; true achieved level is Lower Eocene.

Geological surveying vessel "Iskatel" has determined $35 \mathrm{bln} \mathrm{m}^{3}$ of gas within the northerneastern Black Sea shelf in Odesa region.

Government program - 2020 stipulates complete provision of Ukraine with its own energy carriers. The fact that Ukraine has renewed oil-and-gas explorations within the Black Sea shelf demonstrates the considerable progress in Ukrainian geological prospecting. According to the estimations by geological explorations, gas reserves within the shelf are not less than $40 \mathrm{bln} \mathrm{m}^{3}$ within the area of 7 thousand $\mathrm{m}^{2}$ of the northern-western Black Sea shelf. Ukraine has sufficient amount of resources to satisfy own gas needs; moreover, Ukraine has the possibilities to extract gas on its own. The papers by A.Ye. Lukinov establish genetic relations between the tectonic and geodynamic peculiarities and conditions of generation, migration, and accumulation of the Black Sea region hydrocarbons and Caspian mega basin, which is considered to be unique in terms of, oil-and-gas bearing capacity. The scientist points out that we have all reasons to state that in terms of the corresponding measures of the Black Sea basin exploration, similar to the Caspian one, the number of oil-and-gas deposits in the Black Sea will be not less than the ones of the Caspian area (Lukin, 2014).

Thus, taking into consideration rather abundant methane content of the Black Sea trough, depths, and their temperature mode, it is obvious that there are all the required prerequisites of methane generation. Basic mass of gas hydrates confirmed by sampling is accounted for Ukraine and Romania; less gas hydrate amounts are accounted for Turkey, Bulgaria, and Russia.

Structure of the Black Sea floor and bed deposits enclosing gas hydrate formations

The author has carried out a detailed analysis of the floor structure from the viewpoint of the sedimentary cover enclosing gas hydrates of rocks; the analysis is of high importance to have good understanding of the conditions for the formation of gas hydrate deposits as well as peculiarities of 
thermal and physical properties of their enclosing rocks to develop further schemes of extracting that valuable

energy resource.

Beginning from the depth of $25-50 \mathrm{~m}$, bed deposits of the Black Sea are represented by gravel and sand. The Black Sea shelf starts from the coast and goes down to the depth of 100-140 m. Generally, at the levels higher than $2000 \mathrm{~m}$ depths, within the lim-its of firths, sedimentations of a steep continental slope are stipulated by river discharge; they are rep-resented by sand, pebbles, and mud bank with shells. Remains of mussels and horse mussels can be found within the shelf. They form so-called phaseoline ooze. Central part of the Black Sea floor, deeper than $200 \mathrm{~m}$, is represented by abyssal plain represented by bluish-grey terrigenous mud; occasionally it is covered with white encrustation of amorphous carbonate limestone. Sedimentation mass occurs on a basalt bed covering the Earth's mantle.

Huge quantities of benthos, plankton, zooplankton, and other biomass defined and evaluated by the scientists of the Institute of the Biology of Southern Seas of the NAS of Ukraine may be additional sources of organics along with endogenous methane. Not only benthos but also some species of plankton was found by the scientists within the hydro sulfuric zone of the Black Sea as well as at the depths being more than $1500 \mathrm{~m}$ near the seafloor. That is an interesting fact confirming genetic connection of the Black Sea with fresh-water complexes. Bathyal zone of the Black Sea bottom, covering both shelf and continental slope depths, i.e. from $200 \mathrm{~m}$ down to $3000 \mathrm{~m}$, is colonized: total amount of zooplankton at the depths of $0-50 \mathrm{~m}$ is within the range of $347-7185 \mathrm{sp} . / \mathrm{m}^{3}$; biomass $29.19-330.98 \mathrm{mg} / \mathrm{m}^{3}$; average values of total number of planktonic organism biomass in bottom sediments in terms of two depth ranges being 1250$1850 \mathrm{~m}$ and 2060-2110 vary from 1867 to 18844 sp. / $0.1 \mathrm{~m}^{2}$ and from 98.91 to $1195.97 \mathrm{mg} / 0.1 \mathrm{~m}^{2}$ respectively. Not less than $100 \mathrm{mln}$ tons of organics per year merged into the lower sea layer being taken by sulfate-reducing bacteria generating hydrogen sulphide. Sediment accumulation rate in the Black Sea in not less than $1 \mathrm{~m} /$ th years, $100 \mathrm{~m}$ per 100 th years, and $1 \mathrm{~km}$ per one mln years.

Thickness of bottom sediments accumulated in the Black Sea basin (within the abyssal plain) is 4-8 times more than the depth of the Black Sea water column; thus, the thickness is from 8 to 16 $\mathrm{km}$. That is the thickest layer of the World Ocean bottom deposit. Analysis of core samples from the depths of several thousand meters under the seabed from various regions of the Pacific and Atlantic Oceans as well as the Black Sea demonstrates that archaea prevail having adapted to live in such a complex environment (Chen, Zhou, Su, Liu, Lu, Wang, 2011).

Archaea live on ooze, mud, and remains, petrified and processed by other organisms. As a result of their activity, archaea generate methane.

According to the literature data and the studies by the Institute of Geological Sciences of the NAS of Ukraine, S.I. Subotin Institute of Geophysics of the NAS of Ukraine, Marine Hydrophysical Institute, and the Department of Marine Geology and Sedimental Ore-Formation of the National Museum of Natural History of the NAS of Ukraine, the generalized crosscut of deep water bottom sediments of the Black Sea is as follows:

1. Modern sediment layer is the surface layer with the thickness up to $1 \mathrm{~m}$ (maximum thickness is $1.09 \mathrm{~m})$ consisting of the alternating thinnest interlayers $(0.5-3 \mathrm{~mm})$ of oozy substance with coccolith inclusions.

2. Ancient Black Sea deposits are characterized by the increased amount of organic substance. The complex consists of three layers:

Upper intermediate layer enriched with organic substance represented by high-plastic grey and reddish-brown (within the areas of decay ooze) micro-layered oozes. That layer thickness is about $0.20 \mathrm{~m}$ (maximum thickness is 0.6. $\mathrm{m}$ ). Upper boundary of the complex is clear due to almost constant availability of turbidities-argillaceous interlayers within its roof.

Middle layer is represented by sapropel being homogeneous, dense, and olive green to black in its color. Its average density is $0.40-0.50 \mathrm{~m}$ at maximum value of $0.80 \mathrm{~m}$.

Lower level is represented by pelitic darkgreyish ooze with the characteristic increased content of organic substance. In addition, they are separated by the interlayers of turbidities.

3. Novoeuxinian deposits are not opened to their full capacity (down to $3 \mathrm{~m}$ from their roof). The opened cut of Novoeuxinian deposits is represented by three benches (Bondarenko, Vytiaz, Zotsenko, 2015):

Upper bench is made up by light grey oozes with the thickness up to $0.40 \mathrm{~m}$. At the top, within the boundary with sapropel level, turbidities interlayer is often observed. There is the same layer (up to $0.1-0.11 \mathrm{~m}$ ) within the lower boundary of the oozes. Lower, there are the benches of terrigenous pelitic muds being plastic, bluish-grey with hydrotroilite interlayers within their lower share. Occasionally, there can be observed a turbidities level (up to $0.12 \mathrm{~m}$ ) within the thickness of the bench; the basis of that level is represented by the interlayers of fine-grained sand, changing upwards into 
muddy sediments, and by inclusions of dense yellowish-brown clay.

The lowest bench, among the opened Novoeuxinian ones, is represented by black hydrotroilite oozes, with occasional minor interlayers of terrigenous blue-grey ooze.

Threegenetictypesofsedimentsaresingledoutinadeep waterpartoftheBlackSea: terrigenous, biogenous, andterrigenous-biogenous. In their texture, sediments are layered, sometimes cryptolayered, with flowing or soft consistency. Biogenous oozes are represented by coccolith, sapro-pel, sapropel-like, and sapropel-coccolith varieties. In terms of physical and mechanical properties, oozes are represented by the types ranging from liquid to high-plastic ones.

Such a detailed analysis of lithological composition carried out by the scientists of the NAS of Ukraine is of high importance; thus, the author of the paper takes it as the basis for the developed methodology to calculate the dissociation rate of various-genesis gas hydrate thicknesses. Those lithological varieties have individual indices of thermal capacity, thermal conductivity, porosity etc. being essential while developing such deposits in future.

Having studied and analyzed numerous national and foreign literature sources dealing with nat-ural gas hydrates, the author of the paper interlinks conditions of their formation in the World Ocean in general and in the Black Sea in particular and bottom sediments being their enclosing rocks. Apart from high pressure and low temperature, such parameters as gas saturation, porosity, and thermal conductivity of a certain lithological difference are of considerable importance.

The author is stick to the hypothesis of hydrate formation from the Earth's crust interior (Maksymova, 2013). Its essence is in the fact that methane outgoes from the Earth's interior through faults in the oceanic crust from deep depths, about several dozens of kilometers. Gas flows go through geological sedimentary layers of sea and ocean floors. Certain conditions (increased pressure -from $11 \mathrm{MPa}$ to $15 \mathrm{MPa}$ and low temperatures - from $5^{\circ}$ $\mathrm{C}$ to $14^{\circ} \mathrm{C}$ ), in terms of the available water, effect natural gases; finally, gas hydrates are formed (Fig. $3)$.

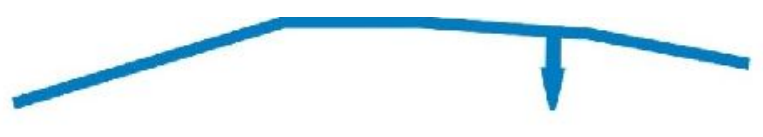

DEPTH TO SEA BOTTOM $800 \mathrm{M}$

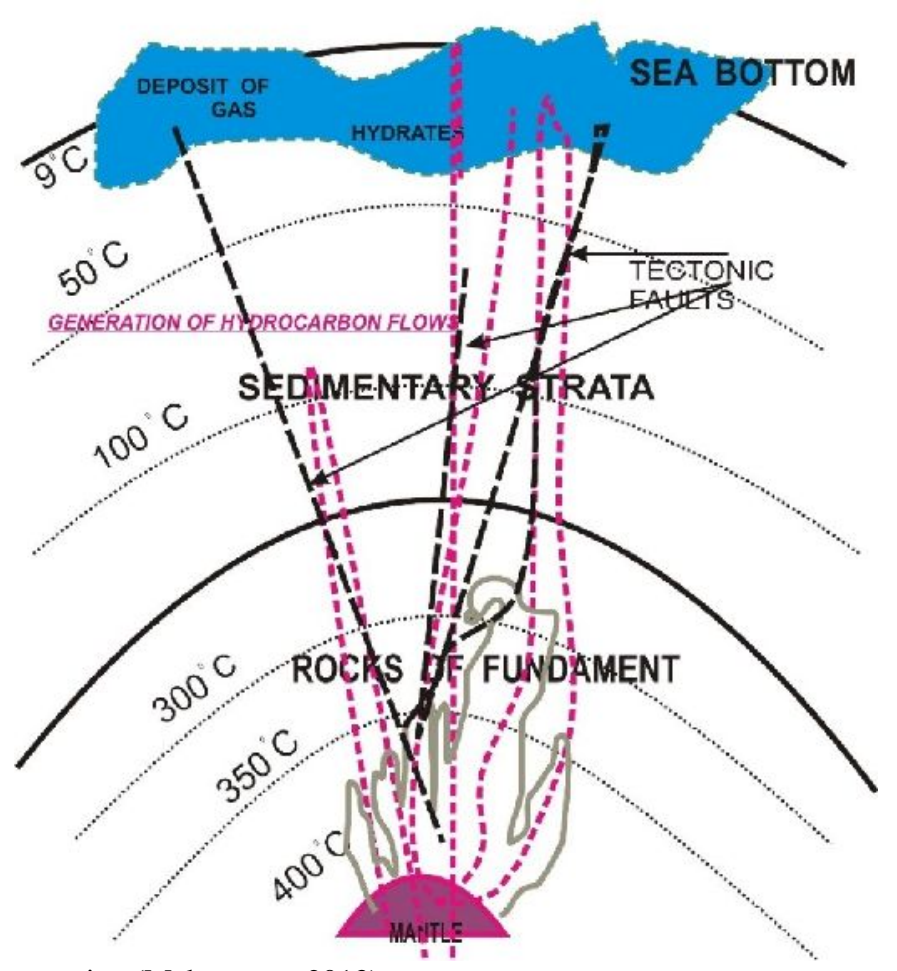

Fig. 3.Scheme of gas hydrates generation (Maksymova 2013).

Thus, within the boundaries of continental slope and deep water bed of the Black Sea trough, there are all the necessary conditions to accumulate natural hydrocarbons in solid (gas hydrate) and liberated (gaseous) state: rather low water temperatures, the required pressure, alternation of porous 
and argillaceous sediments in the cut, wide-scale gas-bearing capacity of the water basin. Geological zones of gas hydrate development are often connected with the development of argillaceous diapers complicated by mud volcanoes. Fragments and separate inclusions of gas hydrates are often found in the outbursts of mud volcanoes. Thickness of gas hydrate deposits may reach up to $400-500 \mathrm{~m}$; in some cases, the thickness may be even $1000 \mathrm{~m}$. As a rule, under-hydrate gas is accumulated under the gas hy-drate deposits. The Black Sea gas hydrates are most often represented by irregular fine inclusions within the semi-liquid oozes, snow-like flakes, or cakes located both on and in the cavities of oozes of various lithological composition. Gas hydrates may develop both in quaternary and Neogene deposits. Deposits containing gas hydrates forms impermeable cover for gases; under-hydrate gas deposits are accumulated under that cover.

It is quite possible that the whole system is in dynamic balance; however, the system, experiencing certain unloading through the funnels of volcanoes and by means of gushers, is refilled at the expense of gas deposits from the deeper levels in the interior.

Scientists of different periods of time developed various classifications of gas hydrate deposits according to the conditions of accumulation and availability: in terms of cryohydrate features, depending upon the phase state of rock fluids (Istomin, Yakushev, 1992), in terms of geological and physical peculiarities (Moridis, 2003), and as for thermobaric condition of the occurrence (Makogon, 1997).

In the author's opinion, a classification is required to achieve final practical objective. The objective is the development of that unusual new energy resource with maximally possible expediency and minimum impact upon the World Ocean environment. That is why classification features are taken in a complex way, i.e. in terms of the origin of the deposits, conditions of their future development, peculiarities of porous medium, and structural features. Basing upon the detailed analysis of the origin of gas hydrate deposits as well as upon structure and lithological composition of gas hydrate enclosing rocks, their corresponding classification in terms of genetic type has been developed. The author has developed classification according to the substance composition of the enclosing rocks and their geological and structural features (Maksymova,

2013):

Type one. Gas hydrate deposits representing continuous deposits on the sea and ocean floors, within shelves and troughs as well as within large tectonic disturbances: along faults, rises, displace- ments, and inside grabens. Those amorphous deposits of gas hydrates are in the form of pure ice occurring as independent layer of considerable thickness (from 2-3 m up to 150-200 m). While selecting the development technique for those deposits, it is required to take into consideration their high and intense specific gas recovery factor reaching 80-90 $\%$.

Type two. Gas hydrate deposits in the form of continuous thicknesses with practically homogeneous, fine-grained structures of gas hydrate masses occurring in shelves and troughs of seas and oceans, mostly in sands, abraded coarse-grained crushed cataclasites, within the boundary and under the seabed; they may also occur in the continents in the permafrost zones within the boundaries of buried faults. Those are uncemented or weakly cemented terrigenous deposits with super capillary porous channels of $0.5-2.0 \mathrm{~mm}$ in diameter. While estimating the reserves and selecting the development technique for the deposits of type two, it should be taken into account that specific gas recovery factor will be up to $60 \%$, and porosity value should be taken within the range of 60-80\%.

Type three. Gas hydrate deposits associated to sabulous, argillaceous, and mud deposits which capillary pores are $0.0002-0.5 \mathrm{~mm}$ being saturated with gas hydrate. Porosity values are within the range of 40-60\%. They may form layered and blanket deposits occurring at different slope angles of anticlinal or synclinal folds, under the sea and ocean floors. In terms of such deposits, specific gas recovery factor is not more than $50 \%$, the process of development will be accompanied by considerable losses at the expense of the available turbulent conditions.

Type four. Gas hydrate deposits within the fragments of rock breccia of various types. Such a deposit type is formed under different geodynamic conditions; it is characterized by rather diverse structure of the enclosing thickness and formed at the points of rock mass displacements under the floors of seas and oceans as well as within the permafrost areas. Values of porosity and permeability will fluctuate within a wide range depending upon the lithological differences of the enclosing thickness and tectonic fragmentation.

Type five. Gas hydrate deposits in the form of vein deposits formed within large masses of magmatic rocks, along faults; correspondingly, gas hydrates occur in the form of large veins. They are of mixed structure - from visible coarse-grained breccia to amorphous ones occurring under the sea and ocean floors; they may be also available within the permafrost zones. In other words, in terms of large veins, cavities, or caves, gas hydrate will not occur in the form of type one, in the form of pure ice with 
the highest values of permeability and specific gas recovery factor. In terms of non-vein areas, socalled border zones of tectonic faults, gas hydrate deposits will be characterized by filtration indices of either type three or type four of the classification.

The classification means further supplementing and correcting taking into consideration the results of geological explorations of gas hydrate deposits according to the current expeditions carried out in different countries.

\section{Conclusions.}

1. Association of the deposits of oil, gas, gascondensate, and gas hydrates of the sedimentary cover to the tectonic structure of the Earth's crust as the additional sign to discover gas hydrate deposits has been proved.

2. Classification of natural deposits of gas hydrates according to the types depending upon their belonging to various tectonic structures, occurrence conditions, and material composition of their enclosing rock has been developed. Distribution of gas hydrate deposits according to their genetic origin makes it possible to be more specified in the selection of rational technological schemes of their development.

3. Methodological approach to evaluate gas hydrate deposits has been elaborated to select the appropriate technological schemes of the processes to extract methane from the World Ocean floor with minimum impact upon the Earth's hydrosphere.

4. It is proposed to develop methods and technologies for gas extraction from natural gas hydrate deposits on the basis of the corresponding deposit types.

The study has been carried out in the National Mining University according to the Law of Ukraine "On the priorities in the development of science and technology" of 12.10.2010,No. 251917, within the framework of Complex Program "Development of methods and technologies of gas extraction from natural gas hydrates and production of artificial gas hydrates to optimize operating processes", (state research subject - 467, 473) under the scientific guidance of Professor Bondarenko, V.I. whom the author expresses her deep gratitude for permanent assistance and extensive support.

\section{References.}

Bondarenko, V., Maksymova, E., Koval, O. 2013. Genetic Classification of Gas Hydrates Deposits Types by Geologic-Structural Criteria. Mining of Mineral Deposits, 115-119. https://doi.org/10.1201/b16354-21
Bondarenko, V., Svietkina, O., Sai, K. 2017. Study of the Formation Mechanism of Gas Hydrates of Methane in the Presence of Surface-Active Substances. Eastern-European Journal of Enterprise Technologies, 5(6(89)), 48-55. https://doi.org/10.15587/1729-4061.2017.112313

Bondarenko, V., Vytiaz, O., Zotsenko, 2015. Hazohidraty. Hidratoutvorennia ta osnovy rozrobky hazovykh hidrativ. [Gas hydrates formation and basics of their recovery]. Litograf, Dnepropetrovsk (in Ukrainian).

Byakov, Y., Krugliakova R. 2001. Gazogidraty osadochnoy tolschi Chernogo Morya - uglevodorodnoe syire buduschego [Gas hydrates of sedimentary strata of the Black Sea - hydrocarbon raw of the

future] Survey and protection of resources. 8, 14-19 (in Russian).

Chen, F., Zhou, Y., Su, X., Liu, G., Lu, H., Wang, J. 2011. Gas Hydrate Saturation and Its Relation with Grain Size of the Hydrate-Bearing Sediments in the Shenhu Area of Northern South China Sea. Marine Geology \& Quaternary Geology, 31(5), 95-100. https://doi.org/10.3724/sp.j.1140.2011.05095

Chong, Z.R., Yang, S.H.B., Babu, P., Linga, P., Li, X.-S. 2016. Review of Natural Gas Hydrates as an Energy Resource: Prospects and Challenges. Applied Energy, (162), 1633-1652. https://doi.org/10.1016/j.apenergy.2014.12.061

Huo, R., Duan, K.B. 2014. Research Status and Trend of Natural Gas Hydrate in China. Advanced Materials Research, (978), 165-168. https://doi.org/10.4028/www.scientific.net/amr.97 8.165

Istomin V., Yakushev V. 1992. Gazovyie gidratyi v prirodnyih usloviyah [Gas hydrates in natural conditions]. Nedra, Moskva (in Russian).

Kobolev, V. 2017. Structural, tectonic and fluid-dynamic aspects of deep degassing of the Black Sea megatrench. Mining of Mineral Deposits, 11(1), 31-49. https://doi.org/10.15407/mining11.01.031

Kobolev, V., Verpakhovskaya, A. 2014. Skopleniya gazovykh gidratov v paleodel'te Dnepra kak ob'ektseysmicheskikh issledovaniy [Accumulations of gas hydrates in the paleodel of Dnepr as an object of seismic researches] Geologiya i Poleznye Iskopaemye Mirovogo Okeana, 1(35), 81-93 (in Russian).

Kvenvolden, K. Robertson J. Simons S. 1988. Methane Hydrate - A Major Reservoir of Carbon in the Shallow Geosphere? Chemical Geology, 71(1-3), 41-51. https://doi.org/10.1016/00092541(88)90104-0

Lee, J.Y., Ryu, B.J., Yun, T.S., Lee, J., Cho, G. 2011. Review on the Gas Hydrate Development and Production as a New Energy Resource. KSCE Journal of Civil Engineering, 15(4), 689-696. https://doi.org/10.1007/s 12205-011-0009-3

Lozynskyi, V., Saik, P., Petlovanyi, M., Sai, K., Malanchyk, Ye. 2018. Analytical Research of the Stress-Deformed State in the Rock Massif 
Around Faulting. International Journal of Engineering Research in Africa, (35), 7788. https://doi.org/10.4028/www.scientific.net/JE RA.35.77

Lukin, A. 2014. Uglevodorodnyiy potentsial bolshih glubin i perspektivyi ego osvoeniya v Ukraine [Hydrocarbon potential of great depths and prospects of its development in Ukraine]. Visn. Natsionalnoyi akademiyi nauk Ukrayini. 5, 31-36. (in

Ukrainian). http://nbuv.gov.ua/UJRN/vnanu_2014_5_8

Moridis, G. 2003. Numerical Studies of Gas Production from Methane Hydrates. SPE Journal Society of Petroleum Engineers, 8 (4), 359-370. https://doi.org/10.2118/87330-pa

Makogon, Y. 2007. Natural gas-hydrates - A potential energy source for the 21st Century. Journal of Petroleum Science and Engineers, 56 (3), 14-31. https://doi.org/10.1016/j.petrol.2005.10.009

Makogon, Y. 2010. Natural Gas Hydrates - A Promising Source of Energy. Journal of Natural Gas Science and Engineering, 2(1), 49-59. https://doi.org/10.1016/j.jngse.2009.12.004

Maksymova, E. 2013. Tipyi mestorozhdeniy gazovyih gidratov $\mathrm{i}$ ih uchet pri podzemnoy razrabotke [Types of gas hydrates deposits and their consideration during underground mining]. Sb. nauchnyih trudov DonGTU. 40, 65-69 (in Russian).

Maksymova, E. 2015. Methodological approach to the development of gas hydrate deposits. Theoretical and Practical Solutions of Mineral Resources Mining, CRC Press Taylor \& Francis Group London, 129-132. https://doi.org/10.1201/b19901-24

Maksymova, E. 2016.Osobennosti mestorozhdeniy gazovyih gidratov pri ih razrabotke $\mathrm{v}$ razlichnyih gorno-geologicheskih usloviyah [Features of gas hydrate deposits when developing in various geological conditions] Visn. Nats. tehn. univ. Ukrayini "Kiyivskiy politehnichniy Institut". Ser.Girnitstvo. 30, 67-75 (in Russian).

Maksymova, E. 2018. Selecting the method of gas hydrate deposits development in terms of the regu- larities of their formation. Mining of Mineral Deposits, 12(1), 103-108.

https://doi.org/10.15407/mining12.01.103

Okuda, Y. 1998. Introduction to exploration of gas hydrates in Japan. Bulletin of the Geological Survey of Japan. 10. 46-53 (in Russian).

Sloan, E.1990. Clathrate Hydrates of Natural Gases. Marcel Dekker, Inc. 1-641

Shnyukov, E., Gozhik P., Krayushkin V., Klochko V., 2007. V treh shagah ot submarinnoy dobyichi gazogidratov [In three steps from the submarine gas hydrate extraction]. Geologiya i poleznyie iskopaemyie mirovogo okeana.1, 32-51 (in Russia). http://dspace.nbuv.gov.ua/handle/123456789 158020

Shnyukov E., Kobolev V., Pasyinkov A. 2013. Gazovyiy vulkanizm Chernogo morya [Gas volcanism of the Black Sea]. Logos, Kyiv (in Russian).

Shnyukov E., Ziborov A. 2004. Mineralnyie bogatstva Chernogo morya [Mineral wealth of the Black Sea]Scien. Issue NAS of Ukraine. 98-105 (in Russian).

Wu, N., Zhang, H., Yang, S., Zhang, G., Liang, J., Lu, J., Zhu, Y. 2011. Gas Hydrate System of Shenhu Area, Northern South China Sea: Geochemical Results. Journal of Geological Research, (2011), 1-10.https://doi.org/10.1155/2011/370298

Yamamoto, K., Terao, Y., Fujii, T., Ikawa, T., Seki, M., Matsuzawa, M., Kanno, T. 2014. Operational Overview of the First Offshore Production Test of Methane Hydrates in the Eastern Nankai Trough. In Offshore Technology Conference (OTC25243-MS). Houston, Texas, United States: OTC. https://doi.org/10.4043/25243-ms

Zhao, J., Song, Y., Lim, X.-L., Lam, W. 2017. Opportunities and Challenges of Gas Hydrate Policies with Consideration of Environmental Impacts. Renewable and Sustainable Energy Reviews, (70), 875-885.

https://doi.org/10.1016/j.rser.2016.11.269 